\title{
Good war/bad war: a war to remember, a war to forget?
}

\author{
Howard Cox \\ Emeritus Professor \\ Worcester Business School \\ University of Worcester \\ City Campus \\ Worcester \\ WR1 3AS \\ e-mail: h.cox@worc.ac.uk
}

\section{Abstract}

This paper uses the distinction that has been developed within organizational studies between collected memory and collective memory to explore and contrast the nature of one multinational company's organizational memory of the First and Second World War. Although the British American Tobacco Company (BAT) experienced severe upheavals as a result of each of the two global military conflagrations of the twentieth century, this paper argues that in terms of its organizational memory there exist clear distinctions between the two. During the course of World War I, BAT was able for the first time to generate a degree of common identity which served it well in the course of its post war expansion during the 1920s. This emergence of a more unified culture, underpinned by a range of common reference points for its staff based on texts, buildings and monuments, facilitated a company-wide collective memory of the war which was subsequently used to promote an esprit de corps across the organization. During World War II, these common cultural reference points were not developed. Thus an organizational memory of the Second World War, during which BAT suffered tremendous commercial setbacks, only emerged many decades after the event and took the form of a collected memory based on individual recollections of some staff members as they moved towards retirement in the 1980s.

\section{Keywords:}

British American Tobacco Company, BAT Bulletin, World War I, World War II, Organizational Memory, Mnemonic Communities 


\section{Introduction}

How does the impact of war leave its imprint on a company's organizational memory? The purpose of this paper is to provide insights into this question by examining how the experience of two world wars helped to shape the organizational memory of the multinational cigarette manufacturing concern, the British American Tobacco Company (BAT).

For an international business enterprise, the disruptive impact of a global conflict will almost invariably act as a catalyst for long-term change as its established working practices and routines react to the circumstances wrought by wartime conditions. Thus, more often than not, the end of hostilities will bring into being a new phase of a corporation's historical evolution. Certainly this is true for BAT. In assessing its corporate history from the perspective of the company's centenary in 2002, the firm's anniversary publication highlighted the critical impact for the international tobacco business of both of the twentieth century's global conflagrations. Hence it noted that "The First World War was to change BAT and the tobacco industry forever" and that equally "The impact of the Second World War on BAT and the cigarette industry was no less profound than that of the First World War" (British American Tobacco, 2002: 27, 57).

Within the context of organizational memory, the company's history set down in its centenary publication would be characterised as an exercise in corporate re-membering or rhetorical history. Formal re-membering on behalf of an organization represents an attempt to produce a compelling narrative of the company's historical evolution in order to emphasize its strengths, its vitality and its durability, in an effort to create a common identity based upon a socially constructed common past (Suddaby, Foster and Quinn-Trank, 2016: 301). As an aspect of organizational memory, such an exercise draws on a reservoir of company-specific documents and artefacts, together with the testimony of serving and retired staff members.

Through such a set of common recollections a business organization, as an institution, can be characterised as one of a number of mnemonic communities that provide a structural shape to a society, such as the members of families or a nation state (Zerubavel 2003: 8). However, the resulting concept of a company's collective memory is open to conflicting interpretations. Olick (1999: 337-343) has made an important distinction between collected versus collective memory, where the former, as in the case of corporate re-membering, relies on an aggregation of individual memories gathered together at a point in time. Using this distinction between collected and collective memory as a point of departure to review organizational memory studies, Rowlinson et al (2010: 70) contrast the methodological individualism that characterises the collected memory approach to organizational memory with the collectivist, social constructionist perspective, which 
"can properly be described as a 'collective memory' approach [in which] organizations can be seen as constituting memory through language and narrative, embodied in rituals and symbols".

This idea of the collective memory of an organization is thus connected to that of a cultural memory in which a variety of tangible aspects of an organization's existence serve to provide individual members with a number of common points of reference. These may take the form of texts, rites, images and buildings that are direct manifestations of the institution in question (Kantsteiner 2002: 182). Where factors such as these assume special significance in relation to an historic event, such as a world war, a broadly common collective memory of the experience may emerge across the organization. Such a collective memory emerges out of common features of the organization's members' lived experiences, reinforced by a series of supporting cultural elements (e.g. texts) created by the institution itself. Drawing on Halbwach's theory of social memory, Olick (1999: 335) notes that whereas "History is the remembered past to which we no longer have an 'organic' relation...collective memory is the active past that forms our identities."

This paper seeks to argue that the form of organizational memory which emerged in BAT relating to the two world wars were actually quite distinct from one another. The First World War had a cultural significance on the organization which was captured in various ways through texts, rites, memorials and buildings, and these served to consolidate a lived experience that was common across a wide range of its staff members. This, it is posited, represented a collective memory that helped to shape the company's identity as it went forward into the 1920s. In contrast, few such common cultural features emerged as a result of the Second World War, which in turn reflected a wide variety of lived experiences on behalf of the company's employees during this period. Only a retrospective, collected memory of the events of 1939-1945 emerged to provide it with a corporate memory of these years; one which had little or no bearing on the post war development of the company's identity.

\section{BAT and World War I}

The roots of the British-American Tobacco Company (BAT) lie in the decision of James Buchanan (Buck) Duke to seek a manufacturing base in the UK for his American Tobacco Company (ATC). Duke's strategy of developing machine-made cigarettes as a platform for dominating the tobacco market in the US during the 1890s had been subsidised and supported by the earnings made from the export of tobacco goods to a range of foreign markets. As these markets were developed, ATC began to face competition from both local firms and British exports which in turn encouraged the Americans to move towards local production in order to secure their market position (Chandler, 1990: 247). The policy of making direct investments in local production capacity, via the acquisition 
of a domestic tobacco firm, had already been employed by ATC in the markets of Japan and Germany before 1900, and the same approach was then applied to the UK (Japan Tobacco 2009: 3642; Chandler, 1990: 432). The Liverpool-based Ogden's company was acquired by ATC in September 1901 and an extensive marketing campaign was developed around that firm's leading brands, most notably its low-priced Guinea Gold cigarettes. In response, 13 of the UK's leading tobacco firms, spearheaded by W.D. \& H.O. Wills of Bristol, formed an alliance by merging their companies under the banner of the Imperial Tobacco Company (of Great Britain and Ireland) in an effort to resist the American invader. A period of protracted commercial warfare ensued, spilling into a number of overseas markets where Wills in particular had been marketing their brands before the turn of the century, until in September 1902 a truce was agreed between Imperial and the ATC (Alford 1973: 250).

Following the cessation of the so-called 'Tobacco War' it was agreed that the export factories of the ATC in the United States, together with those belonging to Imperial and Ogden's in Britain, along with ATC's and Imperial's various overseas investments outside of these countries, should be managed collectively. It was for this purpose that the British-American Tobacco Company was created as, in effect, the international division of the ATC and Imperial. Owned two-thirds by ATC and one-third by Imperial, BAT thus inherited a number of British-based manufacturing facilities, including most significantly Ogden's export factory in Liverpool and that belonging to the Wills branch of Imperial at Ashton Gate in Bristol. As an Anglo-American joint venture, BAT initially operated with a local headquarters in each of its two 'home' territories; one in New York and one in London. The company's office in London, based in a relatively modest building called Cecil Chambers in the Strand, was designated as the firm's registered headquarters even though, at this stage, the main power resided in New York with Duke and his American colleagues (Cox 1989: 45-47). This division of responsibility within BAT was altered radically in 1911, following a ruling by the American Supreme Court which found Duke's ATC to be in contravention of the terms of the Sherman antitrust laws and ordered the company to be broken up, with its institutional shareholding in BAT sold off (Cox 2000: 117-19). One result of this was that James Duke now became personally a major shareholder in BAT (Hannah 2006). From this point forward the management of BAT was consolidated in London and Duke, who in 1912 relocated to England as the company's Chairman, put in place a substantial investment strategy that involved building further factories in Southampton, London and Liverpool (Batchelor-Smith 1969; Jones n.d.). To set the seal on the move, BAT began the construction of a new prestigious headquarters in London's Millbank district, sited opposite the Houses of Parliament and named Westminster House, for which Duke laid the foundation stone in 1913. The pre-eminence of its London headquarters remained a feature of BAT's management 
organisation throughout the rest of the twentieth century. However, before the building of Westminster House had been completed the outbreak of war in Europe sent Duke himself scuttling back to the safety of Fifth Avenue, at which point his active role in the company's management rapidly diminished (Durden 1987: 168). Duke's mantle of power was ultimately assumed by Hugo Cunliffe-Owen, who had joined BAT from the Wills branch of Imperial as the new firm's first Company Secretary in 1902 and who, during the course of the war, spent time working alongside Duke in BAT's New York headquarters (Tobacco 1917).

It was not until February 1915 that Westminster House was ready for occupation, and by this time the advent of the war meant that many of the company's young male members of staff had volunteered to serve in the armed forces. Recruitment to the military was particularly high amongst employees from BAT's large factories in Bristol and Liverpool, with the latter city an early target for Lord Derby's efforts to encourage enlistment amongst staff in the local business community (Gough 2004: 438; Simkins 2003: 240-242). With early recruitment campaigns targeting such workers in urban areas through the medium of "pals battalions", many BAT employees found themselves thrown together as they signed up for military service. It was, for example, common for these BAT men to be seconded to the same regiments located in Gloucestershire and Lancashire, and also to find their paths crossing once they were posted abroad for active service. As they were still employees of BAT, which continued to pay them anything up to one-half of their wages, many of these newly-enlisted soldiers engaged in correspondence with their work colleagues back in Britain. This ongoing communication was later stimulated by parcels of cigarettes and tobacco that the company sent to their staff engaged in the front line, subsidised by voluntary donations from employees to a cigarette fund (BAT Bulletin May 1915).

Soon after the move to Westminster House had been completed Frank Shepherd, an employee at BAT's new headquarters, took the initiative of developing a staff magazine in the form of "a weekly pamphlet, giving extracts from letters from our soldier confrères and other interesting information." Shepherd engaged another BAT employee with 25 years' experience of the journalistic world, H.S. Wheatley, to take on the role of editor and on 17 April 1915 the BAT Bulletin was launched. Dispatched by post to staff serving with the military forces, it was intended to act as a medium between those at the front and those who continued to work for the company at home. The publication was also mailed to staff working in BAT's various foreign branches in return for a subscription. From its initial modest issue comprising of four pages, within the space of two months it had grown to fill sixteen tightly-set pages of print interspersed with small photographs of BAT staff who were now serving the colours. By this time the cost of the enterprise had been underwritten by the directors of the company and thus the magazine was no longer reliant purely on voluntary 
subscriptions. Once established, the Bulletin provided a detailed account of the experiences of military life during the First World War as seen and reported by its own staff members. As a result of the circulation of the Bulletin to both staff at home and those serving abroad - largely, but not only, on the Western Front - the experiences of the war as reported by BAT employees tended to crossreference one another. News was sought and best wishes were offered and dispatched to colleagues now miles apart from one another. The Bulletin thus emerged as a BAT-specific microcosm of the war as a whole. In its pages, accounts of extraordinary courage were set alongside a growing number of epitaphs memorialising those who had been killed in action. As early as August 1915 twelve staff from the Bristol factory, five from Liverpool, one from the factory in London and one member of staff from BAT's headquarters had lost their lives (BAT Bulletin August 1915): the final tally of BAT's war dead amounted to 353 from a total of 3,385 who joined up (British American Tobacco 2002: 29).

As well as providing the company with a detailed account of the part played by its staff during the First World War, the Bulletin also increasingly acted as a unifying force across BAT's group of international enterprises during this period. At the outbreak of the conflict, BAT operated abroad through a range of associated companies located in the British Empire as well as in markets such as China, Brazil and Germany. In 1914, BAT's management quickly sought to negotiate the sale of its assets in Germany, in relation to which it reached an agreement with the Deutsche Bank (Cox 2000: 134). Thereafter the whole of BAT's multinational organisation was able to find common cause in the war, with employees from its various international branches all engaged in fighting the same foe. Towards the latter stages of the war, the masthead of the Bulletin reflected this unifying feature of the conflict (Cox 2008: 203). Originally dedicated to the staff of BAT who had joined His Majesty's Forces, the journal later adopted the motif of a ship wreathed in the names of the various foreign outposts of the company and was published in honour of "the staff of BAT and its Associated Companies who are fighting in the allied cause." The contents of the publication were structured geographically to reflect its international identity, serving to emphasise how the war brought the previously disjointed elements of the group together. At its height during the war 4,300 copies of the weekly publication were being printed and circulated to BAT staff both at home and abroad (BAT Newsletter November 1965).

As the war progressed, the company devoted space in Westminster House to create a museum, known as the Heroes' Gallery, in which to exhibit mementos brought or sent back from the front line by serving staff and which became a focal point for staff visiting while on leave from active duty (BAT Bulletin June 1915). The museum's curator, a Mr Reggie Clarke, assembled a wide variety of memorabilia and it was claimed to be one of the finest collections of war relics (BAT Newsletter 1965: 11). The following note from the BAT Bulletin of May $15^{\text {th }} 1915$, laced with a dose of office 
humour, serves to exemplify the type of exhibit: "Our museum is filling up. Mr. A. E. Aldridge has kindly loaned a dart which is used by aviators. These darts are thrown out in handfuls of twenties, and their velocity at point of striking is so great that they penetrate right through a man's body. Mr. Mulholland has lent a stick which was taken from a German soldier at Duala in the Cameroons, and presented to him by one of our officers. The stick was used for birching the natives, and Mr. Shepherd [editor of the Bulletin] has been thinking how useful it might be nearer home. One of the Sub-Editors has already removed his seat to a trench nearer the Order Department." Presumably the museum's exhibits were returned to their owners at the end of the war, when space in Westminster House was required for the more prosaic needs of commerce.

A book was also opened at the London headquarters soon after the start of the war to record the names of staff who visited while on leave, and these were recorded in the closing page of each issue of the Bulletin together with contributions made to the cigarette fund. The new building on Millbank thus developed an emblematic quality both as a focal point for all the staff of the organisation and as sign of the company's permanence in a world torn asunder by the conflict (Decker 2014). When the war finally ended in an allied victory, the Bulletin was retained as BAT's house journal and the masthead was revised to show Westminster House inset into a field of tobacco leaves somewhere in BAT's global periphery (Figure 1) (BAT Bulletin May 1920). Now the contents of the Bulletin featured accounts of BAT's frontline staff as they sought to develop the demand for cigarettes in international markets far and wide. The majority of these salesmen were veterans of the war and were well-served in pursuing their exploits on behalf of BAT by the resilience they had developed when facing the threats and deprivations of military life. This was reflected in a corporate culture which strongly featured both male sporting prowess and the need for a robust constitution. BAT staff members represented the firm or its branches in a wide range of competitive sports, which in some cases the company endorsed through the donation of trophies bearing the names of various directors. Additionally, notwithstanding the fact that Chairman Hugo Cunliffe-Owen was an avowed abstainer, the traditional link between tobacco and alcohol consumption was a corporate sine qua non, particularly amongst BAT's many itinerant employees engaged in servicing remote foreign markets.

Figure 1 here

The three mastheads of the BAT Bulletin

Memories of the war remained active among staff for years after the conflict had ended and, from time to time, these were used to embellish accounts sent to the Bulletin reporting marketing 
campaigns in far-flung outposts. An example of the genre, submitted for publication by an employee in Java in 1923, even reprised the censorship that had previously applied to correspondence from the front during the war, viz: "On approaching the village of --- we halted, and, as in Flanders, advanced in single file, our two selves, wearing very short shorts and ingratiating smiles, formed the skirmishing patrol, whose primary duty it was to thrust relevant advertising material under the nose of a slightly sceptical market..." (Cox 2008: 206). In 1922, as a mark of respect for those employees who lost their lives during the war, BAT's London-based directors arranged for the erection of an imposing bronze war memorial in Westminster House, and this was unveiled with all due ceremony on 3 July before members of the families whose loved ones had not returned (British American Tobacco Autumn 1998: 10). In common with the broader cult of commemoration after the First World War, the plaque listed the names of every staff member who had been killed in action (Gough 2004: 436). The unveiling ceremony was covered in detail by the BAT Bulletin (July 1922) (Figure 2) and the journal, now issued monthly, also generally carried a feature on the Armistice Day services each November during the 1920s.

Figure 2 here

Unveiling the memorial plaque to honour 353 BAT staff who lost their lives in the First World War

Along with the inevitable dislocations that it wrought, the war did serve to provide BAT with a positive stimulus in terms of its overall sales of cigarettes and tobacco. Early in 1916, as the newlyinstalled coalition government of Lloyd George sought to prosecute the war with more active central support, the War Office invited tenders for the supply of duty-free tobacco and cigarettes to the troops abroad. The Wills branch of Imperial obtained a substantial amount of these orders, and subcontracted its allied firm BAT to fulfil the requirements (Alford 1973: 321). Thus the large quantities of Wills' Woodbine and Gold Flake cigarettes that became synonymous with the trench warfare of 1914-18 were produced in the factories of Liverpool, Bristol and Southampton owned by BAT (Cox 2000: 134). The required additional production capacity was created partly by switching the manufacturing of 4 billion cigarettes per annum destined for the Chinese market to a new factory in the United States, and by expanding operations in both Liverpool and Southampton (Cox 1997: 49). According to the tobacco trade press, the company's sales rose 20 per cent as between the last three months of 1915 and the same period in 1916 (Tobacco 1917). BAT's annual profits, which in September 1914 had been recorded as standing at $£ 1.4$ million, had by September 1919 reached almost $£ 5$ million (Cox 2000: Appendix 1). 


\section{BAT and World War II}

In the two decades between 1919 and 1939, BAT first consolidated and then expanded its global cigarette business. Immediately the First World War ended the company began to raise additional capital to support fresh investment. The volume of BAT's ordinary shares rose from $£ 6.25$ million in 1918 to $f 16$ million by 1920 , with a further rise to $f 23.5$ million in 1926 . Production capacity was expanded in a wide range of the company's leading overseas markets and expatriate salesmen were dispatched far and wide, armed with sophisticated marketing support including mobile cinema vans, to promote cigarette brands developed for specific market conditions. Support for local farmers to engage in domestic tobacco leaf production was stepped up, most notably in the large markets of China and India (Cox, 2000).

The company's internal figures for the year ending September 1921 show that, at this time, the majority of its international sales were located in Asia. By far the most important of these markets was China which alone accounted for 50 per cent of its foreign sales; British India and British Malaya were responsible for a further 20 per cent. In addition to these, the markets of South Africa, and the British Dominions of Canada, Australia and New Zealand accounted for 16 per cent. Expanding out beyond this group of core territories during the 1920s and 1930s, BAT's global reach extended considerably. In North Africa a substantial market was developed from its base in Egypt, and the company later expanded in West and East Africa from the British colonies of modern-day Nigeria and Kenya respectively. By far the most important area of growth between the wars, however, was in the western hemisphere. Apart from Canada, in 1921 only Brazil constituted a market of any great significance for BAT in the American continent. Thereafter, the markets of Latin America assumed a much higher profile, particularly those of Argentina, Chile and Mexico. In 1926, moreover, BAT acquired the US tobacco manufacturer Brown \& Williamson of Louisville, Kentucky, and thereby laid the foundation for a huge expansion in the domestic market of its former majority owner, the American Tobacco Company, against whom during the 1930s it became a major competitor (Kluger 1996: 93; Tennant 1950: 300). Overall, between 1921 and 1939 the share of BAT's overseas sales accounted for by its activities in the western hemisphere grew from 13.5 per cent to 40 per cent. As a result the firm's market in China, although it more than doubled its consumption of cigarettes per annum during this period, saw its relative share of BAT's foreign sales decline from 50 per cent to 30 per cent of the total between the two world wars (Cox 1991: Appendix 4).

As can be inferred from the above, when Britain declared war on Germany on 3 September 1939 the immediate impact on BAT's global cigarette sales was of limited significance. Outside of 
Germany itself, BAT's main areas of activity in Europe at this time were the three markets of Holland, Belgium and Denmark which together amounted to annual sales of around 3.5 billion sticks, or less than 3 per cent of the overall total. These three markets were duly lost to BAT in 1940 following the German occupation. In Germany, the company had re-entered the market in a small way during 1926 when it set up a factory in Hamburg, but had made a much more significant investment in 1933 through the acquisition of the Dresden-based tobacco firm of Haus Bergmann. During the pre-war Nazi administration, BAT's output had been integrated into a national cigarette cartel operated on behalf of the authorities in Berlin by Philipp Reemtsma. Thus on the outbreak of the war, BAT simply placed their operation in Germany under the control of its German lawyer, Dr Günther Buch, so that the Hamburg factory and the Haus Bergmann operations in Dresden continued to operate under Reemtsma's co-ordination (Elliot 2017). In contrast to the situation in 1914, therefore, BAT did not attempt to sell off its assets in Germany during the war, although its internal figures did cease to record any sales there after the year ending September 1939 at which point they had stood at 4 billion sticks per annum, making it BAT's largest single market in the countries of Europe (Cox 1991: Appendix 4).

Despite its negligible impact on the company's global sales, the outbreak of the military conflict in Europe did have one extremely significant consequence for BAT's corporate organisation. During 1938, with the war against Germany appearing increasingly likely, BAT purchased Rusham House, a small country house estate in Egham, Surrey, south west of London and near to the chairman Sir Hugo Cunliffe-Owen's own residence in Sunningdale (BAT News Autumn 1983). A few days before the formal declaration of war, employees of the company's headquarters in London were evacuated from Westminster House, which was requisitioned by the Ministry of Fuel and Power, to these recently-acquired premises in Surrey (BAT News Spring 1984). This remote outpost was a far cry from the company's prestigious location on Millbank and hence the outbreak of the war meant that the nerve centre of BAT's global operation had retreated into a remote location with which few, if any, of the company's employees outside of the metropolis could identify (Figure 3). Hard on the heels of this move, the younger male members of BAT's staff based in the UK received their call-up papers and were thus obliged to take temporary leave from the company. Their departure led to the employment of a batch of young clerical assistants, invariably female, in relation to which one longstanding male employee later recalled "without pride" that "we were chauvinistic, and the term 'temp' was used in a slightly derogatory sense"(BAT News Spring 1988). The arrival of these newcomers led to a palpable shift in the culture of BAT's headquarters which, at least for the duration of the war, took on a less formal complexion. 
Figure 3 here

BAT's Headquarters at Westminster House and Rusham House

The mandatory conscription of young males into the British armed forces at the very outset of the war was organised on the basis of age-groups rather than by occupation or geographical location. This centrally-controlled system of conscription did not maintain any of the pre-war affiliations amongst the men concerned, as had frequently been the case in the early years of World War I when Lord Derby's strategy of marshalling men into the so-called "pal's battalions" had ultimately led to the decimation of numerous local communities (Simkin 2003: 242). Moreover, few of these newly conscripted recruits were initially posted abroad, but rather sent to military training camps within the UK for a period of time to be prepared for active service at a later date. When the moment for posting abroad came, these soldiers would more often than not find themselves serving in locations far removed from Britain, often in the highly mobile conditions around the shores and islands of the Mediterranean Sea or in India and South East Asia. Under these circumstances, ongoing communication with the company in London was minimal. No in-house BAT journal equivalent to the BAT Bulletin emerged from these wartime conditions to provide a contemporaneous corporate memory of the conflict. After the war ended, an informal magazine entitled Smoke Rings was developed at BAT's Egham headquarters by the underemployed advertising manager, Andrew Spiller, which was designed not as a formal mechanism of corporate communication but as a round-up of social events focused on the employees based at Rusham House. This homespun, light-hearted magazine made no reference to its more seriously-minded predecessor, the BAT Bulletin, and ceased publication following Spiller's retirement in 1952, one year before BAT were able to return their staff to the comparative opulence of a refurbished Westminster House (Figure 4) (BAT News Spring 1982).

Figure 4 here

BAT in-house publications 1919 and 1949

Notwithstanding from the relocation of their headquarters to Rusham House and the conscription of their British-based male members of staff, during the first two years of the war BAT was able to continue its commercial activities outside of the UK relatively unhindered by the conflict. Despite losing control over its operations in the German-controlled markets of Europe (including the Channel Island of Jersey), the growth in sales elsewhere continued unabated and the company posted a new annual sales record of 150 billion sticks for the year ending September 1941, although 
these were generated in part through a cut in margins and led to a fall in profits (Cox 1999: Appendix 1 and 4). The upward trajectory in sales was brought to an abrupt end in December 1941, however, following the entry into the war of Japan. Within the space of a few months at the beginning of 1942 BAT suffered the loss of its markets in China, Java, British Malaya and Indo-China, amounting to a decline in its overall sales by one third year-on-year. This financial setback was compounded by the loss of many of its expatriate staff now interned as prisoners of war by the occupying Japanese military forces. For these employees, the three and a half years spent in captivity brought extreme deprivation and suffering which not all of them were able to survive. "It was", recalled one internee who was ultimately liberated in August 1945 from a prison camp on Hong Kong island, "as if the passengers of a large liner had been wrecked on an island and had to make homes for themselves by a combination of ingenuity and the few things they had been able to salvage"(Stericker 1958: 158). This BAT employee, who had been posted by the company to China in 1935, was appointed Administrative Secretary of the PoW camp and kept detailed records which he later used to publish a harrowing account of his experiences entitled "A Tear for the Dragon".

The tremendous dislocation brought about by the entry of Japan into the war significantly hampered the ability of BAT to keep accurate records of the whereabouts and wellbeing of their staff compared with the situation in relation to the First World War. In addition, the ravages of the blitz together with the move of the company's headquarters from Millbank to Egham, and back again, meant that many company records were destroyed or simply thrown away to ease the requirement for transportation. BAT's centenary brochure noted in relation to the Second World War that "Company records of how many employees served in the forces and what decorations were awarded have been lost" (British American Tobacco 2002: 58) This may have been partly responsible for the fact that the Company's memorial to the employees who were killed during the conflict of 1939-45 does not contain any specific names, in marked contrast to the plaque that was unveiled at Westminster House to commemorate the fallen of World War I. The relatively simple memorial to those members of staff who died during the Second World War was originally erected in the parish church of Egham, as the company continued their occupation of Rusham House well beyond 1945, and was perhaps intended to serve in part as a tribute to all those killed during the war, rather than purely as a memorial to the BAT employees who died as had been the case after the First World War (Figure 5).

Figure 5 here

BAT War Memorials 
The catastrophic fall in BAT's cigarette sales between 1941 and 1942 amounted to an overall decline of approximately 25 per cent. The loss of key markets in the Far East was hardly compensated for by increased sales in Egypt and India as BAT's cigarettes were requisitioned for the troops. The quantities involved were nothing like sufficient to compensate for the sales lost elsewhere, although in India they did expand from 10 billion sticks in 1941 to 20 billion in 1945 (Basu 1988: 117; Cox 1991: Appendix 4). Duty free sales to troops and prisoners of war also helped to boost production in BAT's UK-based factories, particularly after 1943. Nonetheless, when the war finally came to an end BAT desperately needed to re-establish their lost overseas markets to restore profitability to acceptable levels. Thus, within weeks of the cessation of the hostilities in Europe, BAT was actively engaged in negotiations with the allied military government in non Soviet-controlled Germany in an effort to recommence cigarette production at its factory in Hamburg (Kehoe and Greenhalgh 2018).

\section{Discussion}

In examining the organizational memory that developed within BAT as a result of the two world wars it is helpful at the outset to briefly examine the points of contrast between the two major military conflicts of the twentieth century. From the perspective of the UK, one feature which clearly distinguished the two events was the degree to which the Second World War was anticipated at least a year before the declaration of war. This allowed for a degree of preparedness on behalf of both the state and commercial organizations such as BAT. With regard to the British government, the National Service (Armed Forces) Act was passed through Parliament on the same day that war with Germany was declared. The Act imposed conscription on all males aged between 18 and 41 who were obliged to register themselves for service and this enabled a recruitment campaign to be implemented immediately on a national basis (UK Parliament website). In turn, this meant that the employees from individual firms were much less likely to find themselves serving together than had been the case during the voluntary scheme of enlistment that operated during the first eighteen months of the First World War.

As far as BAT was concerned, the strong likelihood of war with Nazi Germany prompted the firm's management in 1938 to acquire an alternative site for its London-based headquarters, thus enabling the evacuation of its staff from Westminster House a few days before the conflict began (BAT News Summer 1996). Along with being more widely anticipated, the nature of the warfare into which Britain entered in 1939 was in marked contrast to that of 1914-18. The over-riding characteristic of World War I was the static campaign of trench warfare along the Western Front. 
Conversely, the later conflict took its lead from the German military model of blitzkrieg, featuring the rapid movement of troops with air support. One important consequence of this more mobile form of warfare was that, whereas in World War I the process of communication between those serving in the trenches and those on the home front was relatively straightforward, in the military situation that developed after 1940 this was far from the case. Thus the scope for BAT's employees to learn of each other's experiences differed markedly between the two wars. Moreover, the lived experience of the war varied far more for individual company employees who, from the outset, were much more likely to be based outside of the UK than had been the case in 1914. For those expatriate staff based in China or India, for example, the impact of the outbreak of war in 1939 was far removed from their daily working lives. On the other hand, those who remained employed by the company in Britain faced a greater personal danger on the home front from air raids and from the threat of invasion in 1940 than their civilian predecessors had done between 1914 and 1918.

It is evident, therefore, that the context within which BAT's organizational memory of the two world wars developed was markedly different. Whereas the First World War provided a number of common points of reference around which a collective memory could coalesce, it was far less the case during the Second World War. These differences can be objectified in relation to elements of the organization's corporate culture such as texts, buildings and memorials, together with the contrasting war experience of the staff members themselves. In terms of buildings, the role played by Westminster House is particularly pertinent. Acting as a symbolic focal point for staff during the First World War, this impressive edifice housed a Heroes' Gallery of wartime artefacts as well as providing a Visitor's Book for the benefit of those members of staff returning from periods of active service. For many of the BAT-affiliated troops stationed on the Western Front, it was noted that Westminster House although "far from sight... is to memory dear" (BAT Bulletin October 1915). The decision to evacuate its headquarters in 1939 , although by no means a purely voluntary action on behalf of the firm's management, left the company bereft of a widely-recognised focal point throughout the Second World War.

By far the most important cultural development linking the history of Westminster House to the First World War was the BAT Bulletin. The publication of this weekly newsletter consolidated the role of the London headquarters as a communication hub for its staff serving in the forces during the war and provided a lasting record of its employees' lives, and tragically also their many deaths, over the course of the conflict. Although company house magazines had emerged quite widely in Britain during the two decades before 1914, the Bulletin seems to be unusual in having its origins specifically as a medium of communication for staff serving in the forces (Heller 2009). Moreover, the Bulletin's role in helping to provide the multinational BAT with a unified corporate culture based 
around the mechanism of bottom-up correspondence from its employees across the organization is quite rare (Cox 2008). In contrast, no such comparable company-wide publication developed from within BAT to play a similar role during the Second World War.

Perhaps the most significant aspect of the Bulletin in helping to promote a collective memory of the First World War on behalf of BAT's employees was the decision to maintain its publication as a house journal after the war had ended. Up until 1929, although having shifted from a weekly to a monthly publication, the Bulletin maintained an identical format and thereby provided a continuing thread linking together the post-war exploits of its foreign-based staff with their earlier military activities. The most direct connection between the post-1918 contents of BAT's house journal and the earlier sacrifices of its staff lay in its annual commemoration of Armistice Day: a counterpart to BAT's own commissioning of the elaborate war memorial which was unveiled in Westminster House in July 1922. This memorial, which was unequivocally dedicated to the individual BAT staff members who were killed during the war, stands in sharp contrast to the more modest plaque commissioned to mark the ending of the Second World War. While it is true that the differences between them serve to reflect a more general trend in the nature of war memorials to be found in Britain relating to the First and Second World Wars (Mosse 1990: 222), it nevertheless points up the extent to which the memorialisation of the Second World War will have had a far smaller impact on BAT's corporate consciousness through its memorialisation of the event as a whole rather than by evoking the memory of individual colleagues who had died during the First World War.

The markets lost by BAT in the Far East following the Japanese military conquest in 1942 carried an additional burden to the company in terms of the imprisonment of 248 of their local expatriate management staff. The plight of these prisoners of war, which included two of the company's directors (Messrs Alexander and Sargant), became a major area of concern for BAT up until their liberation and their welfare, insofar as it was possible for the company to ascertain it, was reported back to shareholders at each of their annual general meetings (Times 1941-44). In terms of collecting and disseminating actual accounts of the experiences of these employees, however, BAT provided no medium of its own in which to relay them to staff members more generally. It was not until the inception in 1982 of an in-house magazine aimed at both pensioners and serving employees, entitled BAT News, that a number of accounts from staff relating their experiences during the Second World War eventually gained a wide circulation within the company (BAT News Spring 1982). Thus in terms of organizational memory, BAT's corporate-based recollection of the Second World War only ever took the form of a collected memory, assembled decades after the event from the recollections of those who both survived the war and were prepared to provide a written account of their experiences for publication. 
For BAT, the Second World War was quite simply an unmitigated disaster. Even as the company began to regain some of the ground it had lost during the 1940s it found itself facing competition from American-style rival brands taken abroad in the service of the US military, notably those of Philip Morris (Kluger 1996: 118-129). The success the company achieved in regaining its position in Germany was completely overshadowed by the complete loss of its huge Chinese business after the 1949 communist revolution. The absence of any positive role played by the events of the Second World War, in terms of the company's post-war reconstruction, provides another contrast with the legacy of the 1914-18 war. The earlier conflict was responsible for a massive rise in the consumption of tobacco in the form of machine-made cigarettes amongst British smokers (Alford 1973: 325) and helped to provide BAT with the production capacity to set in motion its huge post-war international sales expansion. Furthermore the company actively projected an image of esprit de corps, through the medium of the BAT Bulletin, to spur on their task-force of foreign-based salesmen as they exchanged their military tunics for the garb of the boxwallah (BAT Bulletin October 1919); transporting cases of cigarettes and a diverse variety of advertising paraphernalia into freshly conquered markets. In this sense, BAT both consolidated the concept of a collective memory relating to the First World War, and made efforts to harness it to the benefit of the firm's post-war development.

How widely this BAT collective memory of the First World War existed among its staff, and how effectively it could be exploited for commercial means, remain matters for conjecture. Nonetheless, it is not difficult to envisage the existence of such a collective memory, particularly among those staff with shared experiences of the fighting. Naturally, over the course of time, the first-hand memories of the war amongst the company's employees would have fallen victim to the normal processes of attrition, notwithstanding the significance of lifetime employment in the company that would have encouraged a strong historical culture (Smith and Simeone 2017: 338). The simple turnover of staff would have served to dilute the proportion of the workforce for whom the experience of the war could be linked with time spent in the service of BAT. After the Bulletin was discontinued in 1930, following a short and unsuccessful spell as a quarterly magazine in a larger format, the collective memory of the war within the firm would have gradually mutated into that of the collective national mythology which was more broadly attached to the First World War. In line with this, it could perhaps be argued that the national British mythologies regarding the two major wars of the twentieth century - based as they have been on images of, respectively, noble sacrifice and determined resistance - find a persuasive resonance with BAT's organizational memories of the conflicts of 1914-18 and 1939-45: the first, a war it was at pains to remember; the second, a war it was relieved to forget. 
References

Alford, Bernard W.E. 1973. W.D. \& H.O. Wills and the Development of the UK Tobacco Industry, 1786-1965. London: Methuen.

BAT Bulletin. April 17 $7^{\text {th }} 1915$. I (1): 1.

BAT Bulletin. May $1^{\text {st }} 1915.1$ (3): 4.

BAT Bulletin. May 15 ${ }^{\text {th }} 1915.1$ (5): 8.

BAT Bulletin. June $12^{\text {th }} 1915$. I (9): 8.

BAT Bulletin. August $28^{\text {th }} 1915$. I (20): 1.

BAT Bulletin. October 23 ${ }^{\text {rd }}$ 1915. II (28): 31.

BAT Bulletin. October $2^{\text {nd }} 1919 . \times(235): 2822$.

BAT Bulletin. May 1920. XI (1): 1.

BAT Bulletin. July 1922. XIII (27): 595.

BAT News. Spring 1982: Intro and 6-7.

BAT News. Autumn 1983: 8-33.

BAT News. Spring 1984: 12-16.

BAT News. Spring 1988: 7-21.

BAT News. Summer 1996. Egham at war.

BAT Newsletter. November 1965. 4: 11.

Basu, Champaka. 1988. Challenge and Change: The ITC story, 1910-1985. Calcutta: Longman Orient.

Batchelor-Smith, L.A. 1969. Loom of memories: A history of Southampton branch of British-American Tobacco Co., Ltd. Southampton: BAT.

British American Tobacco. 1998. Pensioners' News: The magazine for British American Tobacco pensioners. London: BAT.

British American Tobacco. 2002. Celebrating our first 100 years. London: BAT.

Chandler, Alfred D. 1990. Scale and Scope: The dynamics of industrial capitalism. Cambridge MA: Harvard University Press.

Cox, Howard. 2008. "Shaping a corporate identity from below: The role of the BAT Bulletin." Management \& Organizational History 3 (3-4): 197-215. doi: 10.1177/1744935908094085.

Cox, Howard. 2000. The Global Cigarette: Origins and evolution of British American Tobacco, 18851945. Oxford: Oxford University Press.

Cox, Howard. 1997. "Learning to do business in China: The evolution of BAT's cigarette distribution network, 1902-41." Business History 39 (3): 30-64. 
Cox, Howard. 1991. "The Global Cigarette: BAT and the spread of international business before 1945." PhD diss., University of London.

Cox, Howard. 1989. "Growth and ownership in the international tobacco industry: BAT 1902-27." Business History 31 (1): 44-67.

Decker, Stephanie. 2014. "Solid intentions: An archival ethnography of corporate architecture and organizational remembering." Organization 21 (4): 514-542. doi: $10.1177 / 1350508414527252$.

Durden, Robert F. 1987. The Dukes of Durham, 1865-1929. Durham: Duke University Press.

Elliot, Rose. 2017. “'Tobacco became his destiny': Philipp Reemsmta and the West German tobacco industry, 1939-1959". Paper presented at the Annual Meeting of the UK Association of Business Historians, Glasgow, June 29 - July 1.

Gough, Paul. 2004. "Corporations and Commemoration: First World War remembrance, Lloyds TSB and the national arboretum." International Journal of Heritage Studies 10 (5):435-455. doi: $10.1080 / 1352725042000299054$.

Hannah, Leslie. 2006. "The Whig fable of American Tobacco, 1895-1913." Journal of Economic History 66 (1): 42-73.

Heller, Michael. 2009. "British company magazines, 1878-1939: The origins and functions of house journals in large-scale organizations." Media History 15 (2): 143-166. doi: 10.1080/13688800902781850.

Japan Tobacco. 2009. The First Century of Japan Tobacco Inc.: Origins and evolution, 1904-2008. Tokyo: Japan Tobacco.

Jones, J. n.d. Cigarettes - Liverpool 5: The story of the Liverpool branch of British American Tobacco Company Limited. Liverpool: Hugh Evans and Sons.

Kantsteiner, Wulf. 2002. "Finding meaning in memory: A methodological critique of collective memory studies." History and Theory 41: 179-197.

Kehoe, Thomas J. and Elizabeth M. Greenhalgh. 2018. "'An indispensible luxury': British American Tobacco in the occupation of Germany, 1945-1948." Business History published online: 22 Jan 2018. doi: 10.1080/00076791.2018.1425391.

Kluger, Richard. 1996. Ashes to Ashes: America's hundred-year cigarette war, the public health, and the unabashed triumph of Philip Morris. New York: Alfred A. Knopf.

Mosse, George L. 1990. Fallen Soldiers: Reshaping the memory of the world wars. Oxford: Oxford University Press.

Olick, Jeffrey K. 1999. “Collective Memory: The Two Cultures." Sociological Theory 17 (3): 333-348. 
Rowlinson, Michael, Charles Booth, Peter Clark, Agnes Delahaye, and Stephen Proctor. 2010. "Social Remembering and Organizational Memory."Organization Studies 31 (1): 69-87. doi:10.1177/0170840609347056.

Simkin, Peter. 2003."The Four Armies, 1914-1918." In The Oxford History of the British Army, edited by David Chandler and I.F.W. Beckett, 235-255. Oxford: Oxford University Press.

Smith, Andrew and Daniel Simeone. 2017. "Learning to use the past: The development of a rhetorical history strategy by the London headquarters of the Hudson's Bay Company." Management \& Organizational History 12 (4): 334-356. doi: 10.1080/17449359.2017.1394199.

Stericker, John. 1958. A Tear for the Dragon. London: Arthur Barker.

Suddaby, Roy, William Foster and Christine Quinn-Trank. 2016. "Re-Membering: Rhetorical history as identity work". In The Oxford Handbook of Organizational Identity, edited by Michael G. Pratt, Majken Schultz, Blake E. Ashforth, and Davide Ravasi, 297-316. Oxford: Oxford University Press.

Tennant, Richard B. 1950. The American Cigarette Industry: A study in economic analysis and public policy. New Haven CT: Yale University Press.

Times. 21 January 1941: 9.

Times. 3 February 1942: 9.

Times. 16 February 1943: 7.

Times. 15 February 1944: 7.

Tobacco. 1917. 37 (434): 41.

UK Parliament website. www.parliament.uk/about/living heritage/transforming society/private lives/yourcountry/overview/conscriptionww2/

Zerubavel, Eviatar. 2003. Time Maps: Collective memory and the social shape of the past. London: University of Chicago Press. 